DOI:10.2478/v10129-009-0006-6

\author{
Joanna Marcinkowska ${ }^{1}$, Lech Boros ${ }^{2}$, Anna Wawer ${ }^{2}$
}

\begin{abstract}
${ }^{1}$ Department of Plant Pathology of Warsaw University of Life Sciences, Warsaw, 02-870 Nowoursynowska 159, Poland, ${ }^{2}$ Department of Seed Science and Technology of Plant Breeding and Acclimatisation Institute, Radzików, 05-870 Błonie, Poland
\end{abstract}

\title{
RESPONSE OF PEA (PISUM SATIVUM L.) CULTIVARS AND LINES TO SEED INFECTION BY ASCOCHYTA BLIGHT FUNGI
}

\begin{abstract}
Seeds collected from 10 cultivars and lines of Pisum sativum of both 'afila' and normal foliage type, inoculated in field by Mycosphaerella pinodes and Phoma pinodella, were evaluated for incidence of fungi responsible for Ascochyta blight. Also seed germination and contamination by other fungi were considered. Surface sterilized seeds were plated on Coon agar medium. A sample contains 50 seeds. Data were taken after 8 days of incubation. Frequency of species occurrence depended not only on characters of cultivars and lines, weather conditions during 1998-2001, but on inoculation treatment. Clear response between cultivars and lines to tested factors was noted. Seeds of normal leaved line 344/87/3 and cv. Rubin were the most inhabited by all fungi, and germinated very poorly. Seeds of eight cultivars and lines, including cvs: Kwestor, Agra, Miko, were less infected and better germinated. Almost $40 \%$ of non-germinated seeds were inhabited by various fungi, but cultivars and lines differences were not clear. Seed infection by ascochyta blight fungi was rather low, reaching from 2.26-11.34 percent, a mean 4.81, but always the highest for $M$. pinodes. Percentage of contaminated seeds by other fungi, mainly saprobic, was always higher, even 5 times, with an average $16.73 \%$. The best for seed germination was growing season of 2000 , while for seed infestation, non-germinated and germinated, 2001.
\end{abstract}

Key words: Ascochyta blight, occurrence, Pisum, seeds reaction, intensity

\section{INTRODUCTION}

Ascochyta blight caused by Mycosphaerella pinodes (Berk. et Blox.) Vesterg. (syn. Didymella pinodes (Berk. et Blox.) Petrak) anamorph Ascochyta pinodes L. K. Jones, Ascochyta pisi Libert and Phoma pinodella (L.K.Jones) Morgan-Jones et Burch, is a serious disease of Pisum sativum L., especially in wet seasons, of many countries over the world, like Canada (Wallen 1974, Xue et al. 1997), Australia (Bretag et al. 1995), France (Roger et al. 1999), Poland (Marcinkowska 2002). The plants may be infected during all development stages (Lawyer 1984, Marcinkowska 1996 b, Xue and Warkentin 2001). When seeds were infected reduction in pea emergence, and in consequence grain yield losses occurred (Bretag et al.

Communicated by Edward Arseniuk 
1995, Xue et al. 1997). Different trials were performed for finding sources of resistance to the fungi responsible for Ascochyta blight of pea (Ali et al. 1978, Clulow et al. 1991, Knappe and Hoppe 1995, Boros and Wawer 2007), but nobody found sources of high resistance to the pathogens. In such situation response of newly released pea lines and cultivars to Ascochyta blight fungi have been tested in some countries (Kraft et al. 1998, Xue and Warkentin 2001, Zhang et al. 2006). Also in Poland recently bred pea cultivars and lines were tested against fungi responsible for Ascochyta blight. The studies were done on plants in fields (Boros and Marcinkowska, 2008 in print) and on seeds since level of their infection can indicate on genotype susceptibility (Marcinkowska 1996a). The investigation of occurrence frequency of fungal species causing Ascochyta blight, especially $A$. pinodes and $P$. pinodella, on seeds of new Polish cultivars and lines was the main goal of the presented work. Ability of seed germination and their contamination when non-germinated and germinated was also reported.

\section{MATERIALS AND METHODS}

In the vegetation seasons of 1998-2001 pea plants of four cultivars: Agra, Kwestor, Miko, Rubin, and 6 lines: 1528/96, 344/87/3, 1166/96, RAH 796, RAH 997, RAH 897, both foliage type, growing on plots in fields of Plant Breeding and Acclimatization Institute (PBAI) at Radzików (Central-East Poland) were inoculated prior to flowering stage with conidial suspension $\left(2 \times 10^{6}\right.$ spores in $1 \mathrm{ml}$ of water) of $A$. pinodes, $P$. pinodella and mixture of both species (Boros and Marcinkowska 2008). Plots of these three treatments and water, as control, were replicated four times. After harvest a sample of 50 seeds was collected from each plot for evaluation. Totally in a year 800 seeds of each genotype were tested from January to March.

Seeds were surface sterilized as follows: $30 \mathrm{sec}$. washing in water with detergent, $60 \mathrm{sec}$. rinsing under tap water, $15 \mathrm{sec}$. keeping in $96 \%$ ethyl alcohol, and $15 \mathrm{sec}$. in $15 \% \mathrm{H}_{2} \mathrm{O}_{2}, 5 \mathrm{sec}$. rinsing in distilled sterilized water. Sterilized seeds were placed into 4 Petri plates $(\mathrm{Pp})$ of $10 \mathrm{~cm}$ diameter, $2 \mathrm{Pp}$ with 12 and 2 with 13 seeds on Coon's (CN) agar medium (Ali et al.1978). Number of non-germinated and germinated seeds, healthy and infected by $M$. pinodes, $A$. pisi and $P$. pinodella, and those transmitting all other fungi was counted after (8) eight days from the time the plates were exposed for three 3 days under dispersed natural day light and next four (4) days to bulbs with fluorescent day light for 14 fourteen hours a day. Fungal species identification procedure was as previously described (Marcinkowska 1997).

Number non-germinated and infected by fungi seeds was expressed in percent of 50 seeds in a sample. For statistical evaluation percents were transformed according to Bliss. The GLM procedure was used to analyze the differences among a factor (SAS 2004). 


\section{RESULTS}

Differences in the ability of seed germination and fungal occurrence on them were found between tested cultivars and lines, treatments and years of the performed studies. When cultivars and lines were compared over years and treatments, the highest (23.4) mean percent of non-germinated seeds was noted for line 344/87/3 and the next (17.4) for cv. Rubin of the same homogenous group (Table 1). The other eight cultivars and lines belonged to

Ability of germination and fungi occurrence on seeds of tested cultivars and lines

Table 1 (mean from treatments and years)

\begin{tabular}{|c|c|c|c|c|c|c|}
\hline \multirow{3}{*}{ Genotype } & \multirow{2}{*}{\multicolumn{2}{|c|}{ Non-germinated seeds }} & \multicolumn{4}{|c|}{ Seeds transmitting fungi } \\
\hline & & & \multicolumn{2}{|c|}{ Non-germinated } & \multicolumn{2}{|c|}{ Germinated } \\
\hline & Percent* & HG & Percent* & HG & Percent* & HG \\
\hline $1528 / 96$ & 10.5 & $\mathrm{~b}$ & 4.7 & $\mathrm{~b}, \mathrm{c}, \mathrm{d}$ & 12.8 & $\mathrm{~b}, \mathrm{c}$ \\
\hline Miko & 9.2 & $\mathrm{~b}$ & 3.8 & $\mathrm{~d}, \mathrm{c}$ & 15.1 & $\mathrm{~b}, \mathrm{c}$ \\
\hline $344 / 87 / 3$ & 23.4 & a & 6.0 & $\mathrm{a}, \mathrm{b}, \mathrm{c}$, & 23.5 & a \\
\hline $1166 / 96$ & 10.3 & $\mathrm{~b}$ & 7.3 & $\mathrm{a}, \mathrm{b}$ & 16.4 & $\mathrm{~b}$ \\
\hline Agra & 11.7 & $\mathrm{~b}$ & 4.3 & $\mathrm{~b}, \mathrm{c}, \mathrm{d}$ & 16.1 & $\mathrm{~b}$ \\
\hline RAH 796 & 8.0 & $\mathrm{~b}$ & 2.2 & d & 12.5 & $\mathrm{c}$ \\
\hline RAH 997 & 11.3 & $\mathrm{~b}$ & 3.6 & $\mathrm{a}, \mathrm{b}$ & 16.6 & $\mathrm{~b}$ \\
\hline Rubin & 17.4 & $\mathrm{a}$ & 9.6 & $\mathrm{a}$ & 21.8 & $\mathrm{a}$ \\
\hline Kwestor & 11.0 & $\mathrm{~b}$ & 3.7 & $\mathrm{~b}, \mathrm{c}, \mathrm{d}$ & 14.3 & $\mathrm{~b}, \mathrm{c}$ \\
\hline RAH 897 & 10.2 & $\mathrm{~b}$ & 4.0 & $\mathrm{~b}, \mathrm{c}, \mathrm{d}$ & 13.1 & $\mathrm{~b}, \mathrm{c}$ \\
\hline Mean & 12.3 & & 4.9 & & 16.2 & \\
\hline
\end{tabular}

percent of a sample;

$\mathrm{HG}$ - homogenous group is marked with the same letter

the second group, with the lowest (8.0) percentage for RAH 796 and next (9.2) for Miko. It was depending on cultivars and lines but percentage of healthy non-germinated seeds was always higher than for seeds transmitting fungi. A mean of non-germinated seed for all cultivars and lines was $12.3 \%$. Frequency of fungi occurrence on germinated seeds reached on an average 16.2 percent and 4.9 for non-germinated. Percentage of non-germinated seeds transmitting fungi was covered by 4 homogenous groups from 2.2 for RAH 796 to 9.6 for Rubin. The differences between cultivars and lines for percentage of germinated seeds on which occurred fungi were statistically significant ( 3 homogenous groups). The highest (23.5) percentage of germinated seeds inhabited by fungi was for line 344/87/3 and the next (21.8) of the same group was cv. Rubin. The lowest (12.5) percentage was 
for RAH 796 and in the same group were also lines 1528/96, RAH 897 and cvs Kwestor and Miko.

When treatments were considered, statistically significant differences existed for all non-germinated seeds, and also those transmitting fungi (Table 2). The highest, respectively 16.2 and 6.9 percentage was for seed samples derived from control treatment. Over double more non-germinated seeds were healthy comparing with non-germinated but transmitting fungi. Percentage of germinated seeds transmitting fungi did not differ significantly between treatments and was from 2 to 4 times higher than for non-germinated.

Influence of field treatments on derived seed germination and transmission of fungi

Table 2 independently on genotypes and years

\begin{tabular}{|c|c|c|c|c|c|c|}
\hline \multirow{3}{*}{ Treatments } & \multirow{2}{*}{\multicolumn{2}{|c|}{ Non-germinated seeds }} & \multicolumn{4}{|c|}{ Seeds transmitting fungi } \\
\hline & & & \multicolumn{2}{|c|}{ Non-germinated } & \multicolumn{2}{|c|}{ Germinated } \\
\hline & Percent* & $\mathrm{HG}$ & Percent* & $\mathrm{HG}$ & Percent* & $\mathrm{HG}$ \\
\hline Control & 16.2 & $\mathrm{a}$ & 6.9 & $\mathrm{a}$ & 14.4 & a \\
\hline Ascochyta & 9.5 & $\mathrm{~b}$ & 4.2 & $\mathrm{~b}$ & 15.6 & a \\
\hline Phoma & 11.3 & $\mathrm{~b}$ & 4.1 & $\mathrm{~b}$ & 19.1 & a \\
\hline Asc. + Ph. & 12.1 & $a b$ & 4.7 & $\mathrm{~b}$ & 15.9 & $\mathrm{a}$ \\
\hline
\end{tabular}

explanation — see Table1; HG - homogenous groups

Treatments: Ascochyta - inoculated with $A$. pinodes; Phoma - inoculated with $P$. pinodella; Asc. $+\mathrm{Ph} .-$ inoculated with mixture of $A$. pinodes and $P$. pinodella

Table 3 Influence of year on seed germination and fungi occurrence independently on genotypes and treatments

\begin{tabular}{|c|c|c|c|c|c|c|}
\hline \multirow{3}{*}{ Year } & \multirow{2}{*}{\multicolumn{2}{|c|}{ Non-germinated seeds }} & \multicolumn{4}{|c|}{ Seeds transmitting fungi } \\
\hline & & & \multicolumn{2}{|c|}{ Non-germinated } & \multicolumn{2}{|c|}{ Germinated } \\
\hline & Percent* & HG & Percent* & HG & Percent* & $\mathrm{HG}$ \\
\hline 1998 & 15.7 & a & 5.9 & $\mathrm{~b}$ & 12.3 & $\mathrm{~b}$ \\
\hline 1999 & 11.4 & $\mathrm{a}, \mathrm{b}$ & 3.1 & $\mathrm{c}$ & 6.6 & $\mathrm{c}$ \\
\hline 2000 & 9.8 & $\mathrm{~b}$ & 1.8 & $\mathrm{c}$ & 13.1 & $\mathrm{~b}$ \\
\hline 2001 & 12.3 & $a, b$ & 9.2 & $\mathrm{a}$ & 32.9 & $\mathrm{a}$ \\
\hline
\end{tabular}

explanation - see Table 1;

$\mathrm{HG}$ - homogenous groups

The differences in seed germination and fungi occurrence on them were statistically significant between years (Table 3). Two homogenous groups were distinguished for non-germinated seeds, with the highest (15.7) percent in 1998 and the lowest (9.8) in 2000. Each year occurred less non-ger- 
minated seeds transmitting fungi than healthy and germinated with fungi, reaching the highest (9.2) percentage in 2001 and the lowest (1.8) in 2000. Data concern fungal occurrence on germinated seeds represented also 3 homogenous groups, with the highest (32.9) percent found as well in 2001 and the lowest (6.6) in 1999.

On seeds of tested cultivars and lines occurred 18 different species of fungi. Eight of them have been pathogenic for plants, with $M$. pinodes, $A$. pisi, P. pinodella and Fusarium solani (Mart.) Sacc., specific pathogens for pea, while Botrytis cinerea Pers.: Fr., Stemphylium botryosum Wallr., Sclerotinia sclerotiorum (Lib.) de Bary and Rhizoctonia solani Kühn have been polyhagous species. In the group of pathogenic species dominated fungi responsible for ascochyta blight of pea, the other five species infected seeds only sporadically. Majority of seeds in the group of other fungi were contaminated by saprobic fungi and only a few infected by pathogenic species, but never by responsible for ascochyta blight, so the other fungi mainly consisted of saprobes. Percentage of saprobic fungi was much higher to Ascochyta blight infected seeds (Fig. 1) for each cultivar, and for a mean (16.73) independly on genotype, was over three times more (4.81).

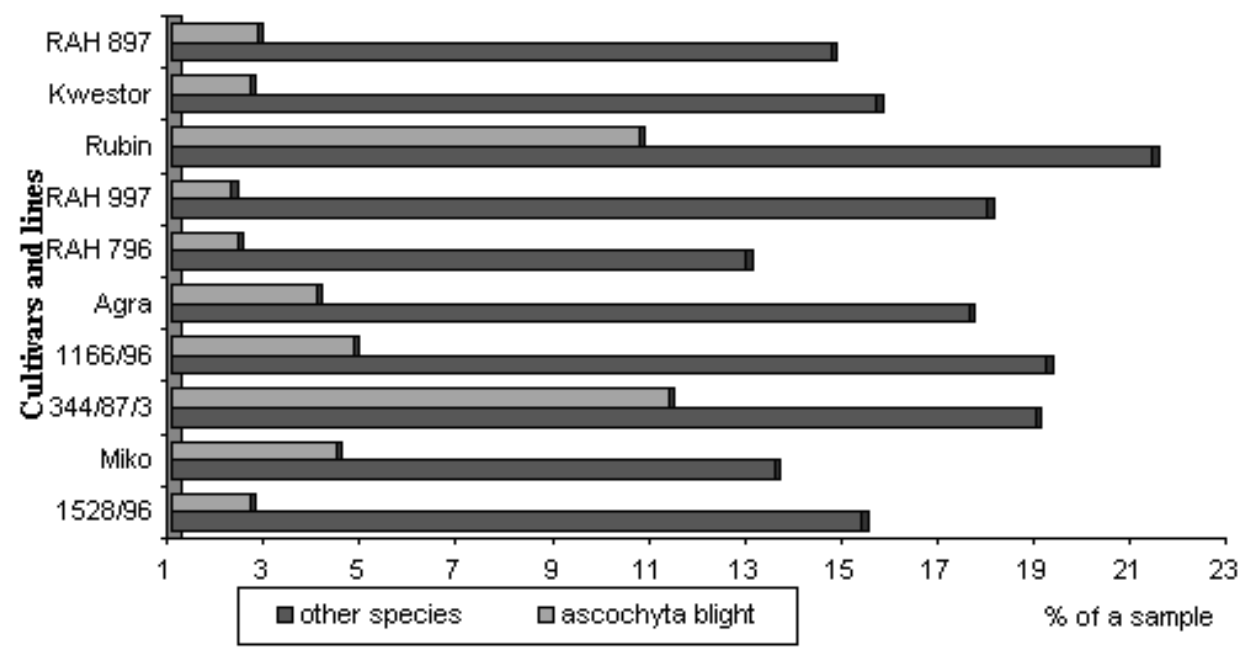

Fig. 1. Occurance of Ascochyta blight fungi (A.pisi, M. pinodes and P. pinodella) and other species on seeds of tested cultivars and lines (mean over treatments and a years)

Among the saprobic species Alternaria alternata (Fr.) Keissler occurred on seeds as the most common and out of Fusarium spp. most often $F$. poae (Peck) Woll. was isolated. F. avenaceum (Corda: Fr.) Sacc., $F$. sporotrichoides and not identified Fusarium isolates were obtained, besides Ulocladium chartarum, Chaetomium spp., Cladosporium spp., Penicillium spp., Aspergillus spp., Mucor spp. Out of ascochyta blight fungi $A$. pinodes was isolated most often, since a mean for cultivars and 
lines, independently on treatments and years, was 3.44 percent of a sample, the next was $P$. pinodella with 1.16 percent and A. pisi occurred only sporadically as on 0.21 percent of a seed sample (Table 4 ).

Table 4

Occurrence of fungi on seeds of the tested cultivars and lines (mean from treatments and years)

\begin{tabular}{|c|c|c|c|c|c|c|c|c|}
\hline \multirow{3}{*}{ Genotypes } & \multirow{2}{*}{$\begin{array}{l}\text { Percent of } \\
\text { sample }\end{array}$} & \multicolumn{3}{|c|}{ Homogenous groups for } & \multirow{2}{*}{$\begin{array}{l}\text { Percent of } \\
\text { sample }\end{array}$} & \multicolumn{3}{|c|}{ Homogenous groups for } \\
\hline & & Sample & Non-germ. & Germ.seeds & & Sample & Non-germ. & Germ.seeds \\
\hline & \multicolumn{4}{|c|}{ Ascochyta pisi } & \multicolumn{4}{|c|}{ Ascochyta pinodes } \\
\hline $1528 / 96$ & 0.22 & $\mathrm{a}$ & $\mathrm{a}$ & $\mathrm{a}$ & 1.67 & $\mathrm{~b}$ & $\mathrm{c}$ & $\mathrm{b}$ \\
\hline Miko & 0.22 & $\mathrm{a}$ & $\mathrm{a}$ & a & 4.06 & $\mathrm{~b}$ & $\mathrm{a}, \mathrm{b}, \mathrm{c}$ & $\mathrm{b}$ \\
\hline $344 / 87 / 3$ & 0.37 & $\mathrm{a}$ & $\mathrm{a}$ & $\mathrm{a}$ & 8.15 & $\mathrm{a}$ & $a, b$ & a \\
\hline $1166 / 96$ & 0.24 & a & a & $\mathrm{a}$ & 3.18 & $\mathrm{~b}$ & $a, b, c$ & $\mathrm{~b}$ \\
\hline Agra & 0.24 & $\mathrm{a}$ & $\mathrm{a}$ & $\mathrm{a}$ & 2.68 & $\mathrm{~b}$ & $\mathrm{c}$ & $\mathrm{b}$ \\
\hline RAH 796 & 0.19 & $\mathrm{a}$ & a & a & 1.81 & $\mathrm{~b}$ & $\mathrm{c}$ & $\mathrm{b}$ \\
\hline RAH 997 & 0.03 & a & $\mathrm{a}$ & $\mathrm{a}$ & 1.61 & $\mathrm{~b}$ & $\mathrm{~b}, \mathrm{c}$ & $\mathrm{b}$ \\
\hline Rubin & 0.31 & a & $\mathrm{a}$ & $\mathrm{a}$ & 7.31 & a & $\mathrm{a}$ & $\mathrm{a}$ \\
\hline Kwestor & 0.06 & $\mathrm{a}$ & $\mathrm{a}$ & $\mathrm{a}$ & 1.89 & $\mathrm{~b}$ & $\mathrm{~b}, \mathrm{c}$ & b \\
\hline RAH 897 & 0.21 & $\mathrm{a}$ & $\mathrm{a}$ & $\mathrm{a}$ & 2.05 & $\mathrm{~b}$ & $\mathrm{~b}, \mathrm{c}$ & $\mathrm{b}$ \\
\hline \multirow[t]{2}{*}{ Mean } & 0.21 & & & & 3.44 & & & \\
\hline & \multicolumn{4}{|c|}{ Phoma pinodella } & \multicolumn{4}{|c|}{ Other fungi } \\
\hline $1528 / 96$ & 0.77 & $\mathrm{~b}$ & $a, b$ & $\mathrm{c}$ & 15.35 & $b, c, d$ & $a, b$ & $\mathrm{~b}, \mathrm{c}$ \\
\hline Miko & 0.15 & $\mathrm{~b}$ & $a, b$ & $\mathrm{c}$ & 13.52 & $\mathrm{~d}, \mathrm{c}$ & $\mathrm{b}$ & $\mathrm{b}, \mathrm{c}$ \\
\hline $344 / 87 / 3$ & 2.82 & $\mathrm{a}$ & $a, b$ & $\mathrm{a}$ & 18.97 & $a, b$ & $a, b$ & a \\
\hline $1166 / 96$ & 1.39 & $\mathrm{~b}$ & $a, b$ & $\mathrm{~b}, \mathrm{c}$ & 19.18 & $a, b$ & $\mathrm{a}$ & $a, b$ \\
\hline Agra & 1.11 & $\mathrm{~b}$ & $a, b$ & $\mathrm{c}$ & 17.57 & $a, b, c$ & $a, b$ & $a, b, c$ \\
\hline RAH 796 & 0.37 & $\mathrm{~b}$ & $\mathrm{~b}$ & $\mathrm{c}$ & 12.95 & $\mathrm{~d}$ & $a, b$ & $\mathrm{c}$ \\
\hline RAH 997 & 0.62 & $\mathrm{~b}$ & $\mathrm{~b}$ & $\mathrm{c}$ & 17.95 & $a, b, c$ & $a, b$ & $a, b$ \\
\hline Rubin & 3.12 & $\mathrm{a}$ & $\mathrm{a}$ & $a, b$ & 21.38 & $\mathrm{a}$ & $a, b$ & $\mathrm{a}$ \\
\hline Kwestor & 0.71 & $\mathrm{~b}$ & $\mathrm{a}, \mathrm{b}$ & $\mathrm{c}$ & 15.66 & $\mathrm{~b}, \mathrm{c}, \mathrm{d}$ & $\mathrm{a}, \mathrm{b}$ & $\mathrm{a}, \mathrm{b}, \mathrm{c}$ \\
\hline RAH 897 & 0.55 & $\mathrm{~b}$ & $\mathrm{~b}$ & $\mathrm{c}$ & 14.72 & $\mathrm{~b}, \mathrm{c}, \mathrm{d}$ & $a, b$ & $\mathrm{~b}, \mathrm{c}$ \\
\hline Mean & 1.16 & & & & 16.73 & & & \\
\hline
\end{tabular}

There were not significant differences between percentage of infected seeds by the last fungus in a sample, neither for non-germinating nor germinating infected seed. Infection of seeds by $A$. pinodes differed statistically and for a whole sample 2 homogenous groups were distinguished like for infected germinating seeds, but for non-germinating 3 groups covered the 
data. The most infected ( 8.15 and 7.31 percent) by this fungus were line $344 / 87 / 3$ and cv. Rubin, representing the same group for a sample and separately on non-germinated and germinated seeds. The lowest $(1.61,1.67$, $1.81,1.89)$ percentage of infected seeds in a sample were found respectively for lines: RAH 997, 1528/96, RAH 796 and cv. Kwestor. The highest (3.12 and 2.82) percent of infection in a seed sample of cv. Rubin and line $344 / 87 / 3$ was also noted for $P$. pinodella and both cultivars and lines represented the same homogenous group. The second group contained eight other cultivars and lines with the lowest percentage $0.15,0.37,0.55,0.62$, respectively for Miko, RAH 796, RAH 897 and RAH 997. Percentage of infected non-germinated seeds by the last pathogen was also covered by 2 homogenous groups, but in case of germinated infected seeds 3 groups were distinguished. Apart from the number of groups, Rubin and 344/87/3 were always the most infected by $P$. pinodella. Differences in other species occurrence on seeds of tested cultivars and lines were not very clear but also statistically documented. The clearest data were for germinating seeds for which cv. Rubin and line 344/87/3 were contaminated by the highest percentage of different fungi, but lines: RAH 796, 1528/96 and cv. Miko by the

Occurrence of fungi on seeds of different treatments (means for cultivars/lines and years)

\begin{tabular}{|c|c|c|c|c|c|c|c|c|}
\hline \multirow{3}{*}{ Treatments } & \multicolumn{2}{|c|}{ Sample total } & \multicolumn{2}{|c|}{ Non-germinated Germin ted } & \multicolumn{2}{|c|}{ Sample total } & \multirow{2}{*}{$\begin{array}{c}\text { Non-germinated } \\
\text { HG }\end{array}$} & \multirow{2}{*}{$\frac{\text { Germinated }}{\mathrm{HG}}$} \\
\hline & Percent* & $\mathrm{HG}$ & HG & $\mathrm{HG}$ & Percent* & HG & & \\
\hline & \multicolumn{4}{|c|}{ Ascochyta pisi } & \multicolumn{4}{|c|}{ Ascochyta pinodes } \\
\hline Control & 0.26 & $\mathrm{a}$ & $\mathrm{a}$ & $\mathrm{a}$ & 2.70 & $\mathrm{~b}$ & $\mathrm{~b}$ & $\mathrm{~b}$ \\
\hline Ascochyta & 0.34 & a & $\mathrm{a}$ & a & 4.97 & $\mathrm{a}$ & a & a \\
\hline Phoma & 0.12 & a & $\mathrm{a}$ & a & 2.78 & $\mathrm{~b}$ & $\mathrm{~b}$ & $\mathrm{~b}$ \\
\hline \multirow[t]{2}{*}{ Asc. $+\mathrm{Ph}$} & 0.17 & $\mathrm{a}$ & $\mathrm{a}$ & a & 3.26 & $\mathrm{a}, \mathrm{b}$ & $a, b$ & $a, b$ \\
\hline & \multicolumn{4}{|c|}{ Phoma pinodella } & \multicolumn{4}{|c|}{ Other species } \\
\hline Control & 0.72 & $\mathrm{c}$ & $\mathrm{b}$ & $\mathrm{c}$ & 18.19 & $\mathrm{a}$ & $\mathrm{a}$ & $\mathrm{a}$ \\
\hline Ascochyta & 0.48 & $\mathrm{c}$ & $\mathrm{b}$ & $\mathrm{c}$ & 14.66 & $\mathrm{a}$ & a & a \\
\hline Phoma & 2.50 & a & $\mathrm{a}$ & a & 18.02 & a & a & $\mathrm{a}$ \\
\hline Asc. $+\mathrm{Ph}$. & 1.46 & $\mathrm{~b}$ & $\mathrm{a}, \mathrm{b}$ & $\mathrm{b}$ & 16.03 & $\mathrm{a}$ & $\mathrm{a}$ & a \\
\hline
\end{tabular}

* Explanation - see table 1; HG - homogenous groups

Treatments: Ascochyta - inoculated with A. pinodes; Phoma - inoculated with P. pinodella; Asc. $+\mathrm{Ph} .-$ inoculated with mixture of $A$. pinodes and $P$. pinodella

lowest.

When seed infection of tested cultivars and lines was considered together for three fungal species responsible for Ascochyta blight independently on treatments and years, line 344/87/3 and cv. Rubin were the most infected, reaching 11.34 and 10.74 percent of such seeds in a sample (Fig. 1). Also the percent of occurrence of other fungi species was the highest for both that cultivar and line. 
Lines RAH 997, RAH 796, 1528/96 and cv. Kwestor showed the lowest percentage of infection, from 2.26 to 2.66. Occurrence of other species was the lowest for line RAH 796 and cv. Miko.

Occurrence of fungal species differed between treatments the seed derived from, but significant differences were only noted for $A$. pinodes and $P$. pinodella (Table 5). For the first species 2 homogenous groups were distinguished for a whole seed sample, infected non-germinated as well as germinated ones. The highest percent of infected seeds was found for Ascochyta treatment. The data obtained for mixture of Ascochyta and Phoma were lower, but covered by both, Ascochyta and Phoma treatment groups. The lowest values showed control treatment, but a little higher seed infection by $A$. pinodes was for Phoma treatment. Differences in percent of seed infected by $P$. pinodella were covered by 2 groups for non-germinating seeds and 3 for a whole sample and germinated seeds. Treatment with Phoma distinguished itself from others by the highest seed infection with $P$. pinodella for a whole sample and separately non-germinating and germinating seeds. The next less infected seeds with $P$. pinodella were for treatment of Ascochyta and Phoma mixture. The lowest percentage was found for Ascochyta, but data of this treatment did not significantly differ from

Table 6 Occurrence of fungi on seeds during 1998 - 2001 independently on cultivars and lines and treatments

\begin{tabular}{|c|c|c|c|c|c|c|c|c|}
\hline \multirow{3}{*}{ Years } & \multicolumn{2}{|c|}{ Sample total } & \multicolumn{2}{|c|}{ Non-germinated Germinated } & \multicolumn{2}{|c|}{ Sample total } & \multirow{2}{*}{$\frac{\text { Non-germinated }}{\mathrm{HG}}$} & \multirow{2}{*}{$\frac{\text { Germinated }}{\mathrm{HG}}$} \\
\hline & Percent* & $\mathrm{HG}$ & HG & HG & Percent* & HG & & \\
\hline & \multicolumn{4}{|c|}{ Ascochyta pisi } & \multicolumn{4}{|c|}{ Ascochyta pinodes } \\
\hline 1998 & 0.53 & a & a & a & 2.48 & $\mathrm{~b}$ & $\mathrm{a}, \mathrm{b}$ & $\mathrm{b}$ \\
\hline 1999 & 0.11 & $\mathrm{~b}$ & $\mathrm{~b}, \mathrm{c}$ & $\mathrm{b}$ & 1.13 & $\mathrm{c}$ & $\mathrm{c}$ & $\mathrm{c}$ \\
\hline 2000 & 0.03 & $\mathrm{~b}$ & $\mathrm{c}$ & $\mathrm{b}$ & 1.99 & $\mathrm{c}$ & $\mathrm{b}, \mathrm{c}$ & $\mathrm{c}$ \\
\hline \multirow[t]{2}{*}{2001} & 0.21 & $\mathrm{~b}$ & $\mathrm{~b}$ & $a, b$ & 6.62 & $\mathrm{a}$ & a & $\mathrm{a}$ \\
\hline & \multicolumn{4}{|c|}{ Phoma pinodella } & \multicolumn{4}{|c|}{ Other species } \\
\hline 1998 & 0.93 & $\mathrm{~b}$ & $\mathrm{~b}$ & $\mathrm{~b}$ & 12.89 & $\mathrm{~b}$ & $\mathrm{~b}$ & $\mathrm{~b}$ \\
\hline 1999 & 0.61 & $\mathrm{~b}$ & $\mathrm{~b}$ & $\mathrm{~b}$ & 7.89 & $\mathrm{c}$ & $\mathrm{b}, \mathrm{c}$ & $\mathrm{c}$ \\
\hline 2000 & 0.73 & $\mathrm{~b}$ & $\mathrm{~b}$ & $\mathrm{~b}$ & 12.44 & $\mathrm{~b}$ & $\mathrm{c}$ & $\mathrm{b}$ \\
\hline 2001 & 2.88 & $\mathrm{a}$ & a & $\mathrm{a}$ & 33.7 & a & $\mathrm{a}$ & a \\
\hline
\end{tabular}

* Explanation see table 1; HG - homogenous groups

those of control one.

Percentage of pea seed infected by species responsible for Ascochyta blight and also occurrence of other species of fungi on tested seeds differed statistically for growing seasons of 1998-2001 (Table 6). The highest (0.53) percent of infected seeds with A. pisi was observed in 1998, but for 
A. pinodes and $P$. pinodella in 2001 , reaching respectively 6.62 and 2.88 . In the same season occurrence of other fungi on seeds was also the highest (33.7). All fungal species occurred less frequently in 1999 and 2000, when temperatures, especially in June, were higher to an average of the period from 1955 - 1996 (Fig. 2). In June 1999 total rainfall was over double to those of 1955 - 1999, on the contrary to 2000 , which was particularly dry, only with $14.4 \mathrm{~cm}^{3}$ of rainfalls. Spring of 2000 was the driest and the hottest of the four growing seasons, reaching higher air temperatures and lower,

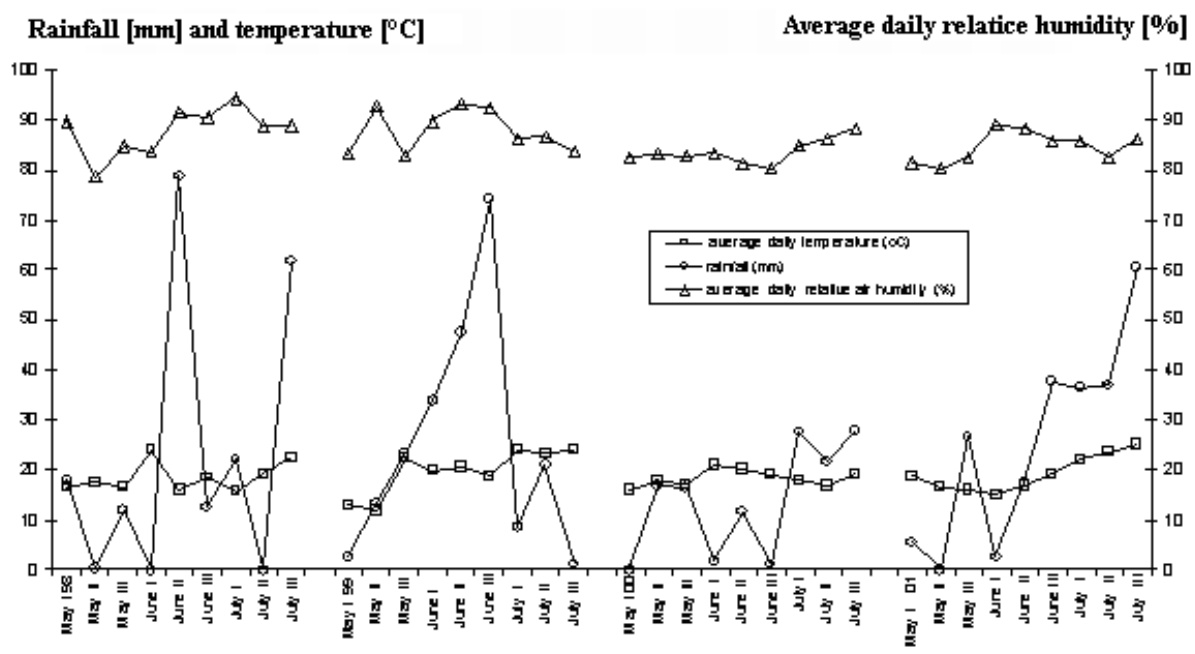

Fig. 2. Weather conditions during growing seasons of 1998-2001 at Radzików (I, II, III decades)

even extremely low, rainfalls in April and June.

\section{DISCUSSION}

Occurrence frequency of Ascochyta blight fungi on seeds obtained at this study was influenced not only by genotype and weather of the growing season (Marcinkowska 1996a, b; Fougereux et al. 2006), but also a way of pea plant inoculation (treatment) done on plots in field (Boros and Marcinkowska, in press). On seeds collected from plants of plots inoculated with $A$. pinodes dominated just this species, and on inoculated with $P$. pinodella also the same last species. Second place in seed infection intensity took results of inoculation with mixture of $A$. pinodes and $P$. pinodella, and the third place of $A$. pinodes. These results looked logically since $A$. pinodes or $P$. pinodella introduced on plants during inoculation gave a particular species priority for development in the vegetation season, on all parts of pea so also on pods and seeds. However, results of inoculation done with mixture of both species indicated on interaction of $A$. pinodes and $P$. 
pinodella, the phenomenon recently studied by Le May et al. (2006). On the other hand, the obtained results could also be partly influenced by spores of these species living in nature. Like it happened for A. pisi. Even plants were not inoculated by $A$. pisi seed infection by this species was noted, for sure, by its conidia existing in an air. This fungus occurred on seeds, but only sporadically, since it was not introduced by inoculation and because growing seasons, especially of 1999 and 2000, were in general dry and hot, so were harmful for plant infection by different pathogens.

Harmful effect of weather on fungal disease development was also proved by results of seed infection by $A$. pinodes and $P$. pinodella, the species introduced on plants. The inoculated plants after incubation period were mainly exposed to conditions of existing weather and as the consequence percentage of seeds infected by species used for inoculation were quite low. The results depended on years being the lowest for 1999 and 2000 , the years of too high temperatures and low rainfalls by the end of vegetation period, the time where pods and so seeds have been in the stage of ripening (Fig. 2). According to Roger et al. (1999) temperature over $20^{\circ} \mathrm{C}$ decreased development of $M$. pinodes, while the disease was able to develop within a few days under favorable moisture and over a wide range of temperatures $\left(15-25^{\circ} \mathrm{C}\right)$. On the other hand such weather increased ability of seeds for germination. Even the occurrence frequency of $A$. pinodes and $P$. pinodella on seeds were not high, the results indicated on different response of ten studied cultivars and lines to $A$. pinodes and $P$. pinodella, the two species mainly responsible for pea Ascochyta blight. The most infected seeds by all three species were for cv. Rubin and line 344/87/3 and also their germination was the poorest. Seeds of these cultivars and lines were also inhabited by the highest percent of all other fungi.

Plants of line 344/87/3 had long vegetation period, high growth so could easily lodged and those characters caused they were much stronger infected. Also Wang et al. (2006) stated that lodging increased severity of Ascochyta blight caused by $M$. pinodes on field pea. The eight other cultivars and lines belonged to the same group of low seed infection and their ability for germination was much better to noted for line 344/87/3 and Rubin. Among them were lines: RAH 997, 796, cvs: Kwestor and Miko. For the last cultivar Xue and Warkentin (2001) found partial resistance to stem and pod infection by M. pinodes. Low seed infection by Ascochyta blight fungi noted in this study for Miko and already stated resistance of this cultivar to M. pinodes (Xue and Warkentin 2001) might be a prove that seed reacted to pathogens similarly like other parts of plant. Li Yonghao et al. (1992) found highly significant relationship between resistance of bean pods and leaves to Colletotrichum lindemuthianum (Sacc. Et Magn.) Bri. et Cav. while Marcinkowska and Borucka (2001) reported significant relationship between bean infection by $C$. lindemuthianum in fields and the fungus incidence in seeds. Positive correlation between seed infection by 
Ascochyta blight fungi and intensity of the disease on leaves, stems and pods during vegetation reported Marcinkowska (1996a) only when intensity of blight in field was at least slight to moderate. But Bretag et al. (1995b) stated no correlation between the level of seed infestation by $M$. pinodes and the severity of the disease. These authors reported only significant reduction in pea emergence when the level of seed infection was over $11 \%$. However, Bretag et al. (1995a) noted close correlation between disease severity and reduction in grain yield.

In the performed studies even plants were inoculated with both fungi, seed infection of all cultivars and lines by M. pinodes occurred more often than by $P$. pinodella. Those results have been in agreement with earlier (Marcinkowska 1996b) reported prevalence of M. pinodes on seeds, leaves, stems and pods but the lowest seed incidence of the second species. Moreover, occurrence frequency of both species in the presented studies, though they were introduced on plants, was lower compared to percentage of infected seeds in years of early ninties (Marcinkowska 1996a,b). The differences might be caused not only by different reaction of another cultivars tested but also weather conditions, very important for fungal diseases development.

\section{REFERENCES}

Ali S.M., Nitschke L.F., Dube A.J., Krause M.R., Camerom B. 1978. Selection of pea lines for resistance to pathotypes of Ascochyta pinodes, A. pisi, and Phoma medicaginis var. pinodella. Aust.J. Agric. Res., 29,841-849.

Boros L., Marcinkowska J.M. 2008. Assessment of selected pea cultivars and lines reaction to ascochyta blight under field conditions with inoculation and impact of disease severity on yield components. (J. Plant Pathol. submited).

Boros L., Wawer A. 2007. Response of pea cultivars to Mycosphaerella pinodes in test under controlled conditions and in field at controlled infection. Zeszyty Problemowe Postępów Nauk Rolniczych, z:522, 157-165 [in Polish with English summary)

Bretag T.W., Keane P.J. Price, T.V. 1995a. Effect of ascochyta blight on the grain yield of field peas (Pisum sativum L.) grown in southern Australia. Australian Journal of Experimental Agriculture.,35, 531-536.

Bretag T.W., Price T.V., Keane P.J. 1995b. Importance of seed-borne inoculum in the etiology of the ascochyta blight complex of field peas (Pisum sativum L.) grown in Victoria. Australian Journal of Experimental Agriculture.,35, 525-530.

Clulow S.A., Lewis B.G., Matthews P. 1991. A pathotype classification for Mycosphaerella pinodes. Journal of Phytopathology., 131, 322-332.

Fougereux J.A., Mériaux B., Olivier V., Sérandat I., Leclerc S., Avrillon M., Cassignol,F., Dagorn, C. 2006. A 20 years overview of pea seed contamination by Ascochyta sp. in France. Poster abstract (C11), Ascochyta workshop on grain legumes in Le Tronchet (Brittany, France) on 2-6 July, 2006

Knappe B., Hoppe, H.H 1995. Investigations on the resistance of peas (P. sativum L.) towards Ascochyta pinodes and Phoma medicaginis var. pinodella. $2^{\text {nd }}$ European Conference of Grain Legumes, 86-87.

Kraft, J.M., Dunne, B., Goulden, D. and Armstrong, S. (1998). A search for resistance in peas to Mycosphaerella pinodes. Plant Disease., 8, 251-253.

Lawyer A.S. 1984. Diseases caused by Ascochyta spp. In Compendium of pea diseases, (ed. D.J. Hagedorn), pp.11-15 American Phytopathological Society, St. Paul, MN., USA

Le May C., Leclerc A., Guibert M., Schoeny A., Tivoli B. 2006. Preliminary results on the interaction between Mycosphaerella pinodes and Phoma medicaginis var. pinodella, two fungi of the ascochyta complex. Poster abstract (C12), Ascochyta workshop on grain legumes in Le Tronchet (Brittany, France) on 2-6 July, 2006

Li Yonghao, Qin Zhiwei, Xu Fengying 1992. Study on the resistance of bean pools and leaves to anthracnose and their correlation. J. Northeast Agric. College 23(1): 17-19 
Marcinkowska J.Z. 1996a.. Ascochyta blight in Pisum sativum L. seeds. Plant Breeding and Seed Science., 40, 59-71.

Marcinkowska J.Z. 1996 b. Frequency of occurrence of Ascochyta pisi Libert, Mycosphaerella pinodes (Berk. et Blox.) Vestergren and Phoma pinodella (L.K.Jones) Morgan-Jones et Burch, the fungi responsible for ascochyta blight on peas. Phytopathologia Polonica., 12, 15-33.

Marcinkowska J.Z. 1996c. Micromycetes on Pisum sativum var. arvense. Acta Mycologica,, 32, 31-39.

Marcinkowska J.Z. 2002. Foliar diseases of Pisum sativum L. in Poland. Plant Breeding and Seed Science., 46, 49-54.

Marcinkowska J.Z., Borucka K. 2001. Colletotrichum lindemuthianum in Phaseolus vulgaris seeds.Plant Breeding and Seed Science., 45, 59-64.

Roger C., Tivoli B., Huber L. 1999. Effects of temperature and moisture on disease and fruitbody development of Mycosphaerella pinodes on pea (Pisum sativum). Plant Pathology., 48, 1-9.

SAS Institute Inc. 2004. SAS/STAT 9.1 User's guide. Cary, NC, USA: SAS Publishing, SAS Institute Inc.

Wallen V.R. 1974. Influence of three Ascochyta diseases of peas on plant development and yield. Canadian Plant Diseases Survey., 54, 86-90.

Wang T.F., Gossen B.D., Slinkard A.E. (2006). Lodging increases severity and impact of mycosphaerella blight on field pea. Can. J. Plant Sci., 86, 855-863.

Zimmer R.C., Sabourin, D. 1986. Determining resistance reactions of field pea cultivars at the seedling stage to Mycosphaerella pinodes. Phytopathology., 76, 878-881.

Zhang R., Hwang S.F., Chang K.F., Gossen B.D., Strelkov S.E., Turnbull G.D., Blade S.F. 2006. Genetic resistance to Mycosphaerella pinodes in 558 field pea accessions.Crop Sci., 46: 2409-2414.

Xue A.G., Warkentin T.D. 2001. Partial resistance to Mycosphaerella pinodes in field pea. Can. J. Plant Sci., 81,535-540.

Xue A.G., Warkentin T.D., Kenaschuk E.O. 1997. Effects of timings of inoculation with Mycosphaerella pinodes on yield and seed infection of field pea. Can. J. Plant Sci., 77, 685-689.

Xue A.G., Warkentin T.D., Greeniaus M.T, Zimmmer R.C. 1996. Genotypic variability in seedborne infection of field pea by Mycosphaerella pinodes and its relation to foliar diseases severity. Can. J. Plant Pathol.18: 370-374 